\title{
Issues of emission evaluation of road-rail vehicles in the aspect of current type approval regulations
}

\begin{abstract}
One of the ways to reduce exhaust emissions from vehicles is to replace worn-out shunting locomotives with road-rail tractors. The main purpose of this solution is to reduce the negative environmental impact of the vehicle and to reduce the fuel consumption compared to a shunting locomotive performing the same work. The tests on exhaust emissions of rail vehicles are carried out on an engine test bench, making it impossible to determine the environmental performance of these vehicles during real operation. Therefore, it is advisable to carry out measurements in real operating conditions in order to obtain reliable reference results. This enables the verification of vehicles ecological indicators in a wide range of operational work parameters. It is possible to obtain reliable results regarding the impact of the tested vehicle on the natural environment in this way and compare them with the applicable emission standards.
\end{abstract}

Key words: engine exhaust emission, road-rail vehicles, fuel consumption, research in real conditions, ecology

\section{Introduction}

Rail transport, as compared to other modes of transport, is characterized by a low share in the total emission of harmful compounds in the transport section. Nevertheless, due to the continuous tightening of emission norms, increasingly more emphasis is placed on the exhaust emission of traction vehicles and new methods are being sought to improve their ecological indicators. The tests on rail vehicles exhaust emissions are carried out on the engine test bench, and the results obtained are compared with the permissible limit values included in the relevant legal emission norms $[3,4]$. Therefore in order to obtain reliable results for various engine operating states, it is necessary to carry out measurements in real operating conditions, for motor vehicles defined as RDE (Real Driving Emissions). The implementation of such tests makes it possible to verify the ecological indicators of vehicles in the wide operating spectrum of their drive systems. It is hence possible to obtain reliable results regarding their impact on the natural environment in relation to the applicable exhaust emission norms $[3,4,6,7,9]$.

This article examines the exhausts emission of harmful compounds during real operating conditions of a rail-road tractor that can perform shunting work on the tracks. The vehicle has a $116 \mathrm{~kW}$ internal combustion engine and meets the Stage IIIB emission norm according to its technical specifications. Road-rail tractors are increasingly used on the domestic and European market by railway and tramway track managers due to their mobility and design features that facilitate the possibility of installing a set of wheel rollers and pull-buffer devices. The road-rail vehicle also allows performing shunting work on tracks. In the case of a vehicle that is to replace a shunting locomotive, information on its ability to roll over wagons is important. For this purpose, it is necessary to obtain an adequate traction force resulting from friction between the rail head and the vehicle tire. A road-rail tractor, in order to carry 10 wagons, needs adequate pressure to push the tire to the track rails. Higher tire pressure on the rail increases the vehicle wagons transporting capacity. An important parameter is also the permissible gross weight that allows the tractor to move on public roads. The most important issue from the point of view of the conducted research is to reduce the negative environmental impact of the vehicle and to reduce fuel consumption compared to a locomotive performing the same shunting work $[1,2,5]$.

The aim of the conducted research was to measure the tractor's ecological indicators during operation on the road without load and on the track with and without load and compare them with the type approval requirements. During the tests, the concentration of gaseous compounds and particulate matter in the exhaust gas was measured. In order to determine the road emission, mass flow rates and signals from the on-board diagnostic system, GPS and METEO were also recorded. Obtained values have been referred to the emission norms for engines with a rated power of $75 \mathrm{~kW} \leq \mathrm{P}<130 \mathrm{~kW}$ (Table 1), as the test vehicle was classed in this power range.

Table 1. Exhaust emissions limit values according to the Stage I, II and IIIB norms $[3,4]$

\begin{tabular}{|c|c|c|c|c|c|}
\hline \multirow{2}{*}{ Norm } & $\mathrm{P}$ & $\mathrm{CO}$ & $\mathrm{HC}$ & $\mathrm{NO}_{\mathrm{x}}$ & $\mathrm{PM}$ \\
\cline { 2 - 6 } & $\mathrm{kW}$ & \multicolumn{4}{|c|}{$\mathrm{g} / \mathrm{kWh}$} \\
\hline Stage I & $75 \leq \mathrm{P}<130$ & 5.0 & 1.3 & 9.2 & 0.7 \\
\hline Stage II & $75 \leq \mathrm{P}<130$ & 5.0 & 1.0 & 6.0 & 0.3 \\
\hline Stage IIIB & $75 \leq \mathrm{P}<130$ & 5.0 & 0.19 & 3.3 & 0.025 \\
\hline
\end{tabular}

\section{Issues concerning measurements of the real} exhaust emission from non-road vehicles

In the aspect of exhaust emissions, internal combustion engines of off-road vehicles are homologated at stationary brake stations. Based on the research carried out in recent years, it should be noted that qualitative and quantitative measurements of exhaust emissions from internal combustion engines performed in laboratory conditions may significantly differ from the results obtained in field conditions. Continuous development and miniaturization of the measuring equipment belonging to the PEMS mobile analyzers group allows to perform increasingly more accurate studies of vehicle ecological indicators in real operating conditions. 
At the same time, the application possibilities of these devices have increased. Thanks to this, it has become possible to take into account the specificity of road/rail traffic for specific groups of machines, including maintaining the size dimensions of the vehicles with the equipment installed within the railway gauge. The apparatus for testing in real traffic conditions requires the use of exhaust gas flow meters. However, due to the engine assembly parameters, this issue is often a problem related to exceeding the permitted dimensions. For this reason, flow characteristics should be determined using information based on: intake manifold air pressure and temperature as well as crankshaft speed. In modern engines it is possible to use data from on-board diagnostic systems.

The assessment of ecological indicators in real operating conditions can be performed in various aspects, most often in relation to the engine operation (specific emission expressed in $\mathrm{g} / \mathrm{kWh}$ ) or to the distance traveled (road emission expressed in $\mathrm{g} / \mathrm{km}$ ). It is also appropriate to make an assessment in the aspect of the vehicle operating parameters variability or the drive system itself. Time density characteristics (TD) have been regularly relied on for several decades in the construction and optimization of internal combustion engines, drive systems and entire vehicles. Using the assumptions, it is possible to determine the combustion engine operation time shares in crankshaft speed and load intervals during tests in a given measurement cycle. They also allow to present the driving characteristics for different speed and acceleration ranges. Therefore, taking into account the operating time, it is possible to characterize the traffic and environmental performance of nonroad vehicles by using a discrete function, which will be presented in the time density characteristics.

\section{Research method}

\subsection{Test vehicle}

The road-rail tractor is adapted to move both on roads and on tracks, be it railway, tram or metro (Table 2). It is intended mainly for moving wagons on railway sidings and shunting works. The vehicle was built using a road tractor for a base and equipped, among others, with a traction and collision system, a rail chassis (front and rear), a hydraulic

Table 2. List of construction parameters of the tested tractor

\begin{tabular}{|l|c|}
\hline \multicolumn{1}{|c|}{ Parameter } & Value \\
\hline Max power & $116 \mathrm{~kW}$ \\
\hline Max torque & $659 \mathrm{Nm}$ \\
\hline Number of cylinders & 6 in-line \\
\hline Fuel supply system & Common Rail \\
\hline Exhaust emission norm & Stage IIIB \\
\hline Specific fuel consumption & $211 \mathrm{~g} / \mathrm{kWh}$ \\
\hline Max travel speed & $40 \mathrm{~km} / \mathrm{h}$ \\
\hline Max pulling force on roads & $45 \mathrm{kN}$ \\
\hline Max pulling force on tracks & $35 \mathrm{kN}$ \\
\hline Tractor mass & $9000 \mathrm{~kg}$ \\
\hline Max cruising speed on a straight track / road & $25 \mathrm{~km} / \mathrm{h}$ \\
\hline $\begin{array}{l}\text { Max cruising speed on arcs and switches } \\
\text { when pulling wagons }\end{array}$ & $5 \mathrm{~km} / \mathrm{h}$ \\
\hline $\begin{array}{l}\text { Max allowed cruising speed on straight track } \\
\text { when pulling wagons with pneumatic brake }\end{array}$ & $10 \mathrm{~km} / \mathrm{h}$ \\
\hline
\end{tabular}

system and braking system (installed on the roof) for braking the transit of attached wagons. A compression-ignition engine in a in-line configuration with a rated power of 116 $\mathrm{kW}$ and a displacement volume of $6.8 \mathrm{dm}^{3}$ was used to drive the tested vehicle $[1,2,5]$.

\subsection{Test route}

The tests in vehicle real operation while performing shunting work were performed at the Łukasiewicz Research Network - Rail Vehicles Institute "TABOR". In the case of the second and third test drive, the tests were carried out according to a new method for rail vehicles designed by the authors. For the conducted research tests, the routes included distances amounting to $1.7 \mathrm{~km}$ for road travel, $1 \mathrm{~km}$ for unladen travel on rail track and $1.3 \mathrm{~km}$ for laden rail track travel. The maximum travel speed of research vehicle on the asphalt road was $23 \mathrm{~km} / \mathrm{h}$, while in the test made on the track for unladen vehicle it was lower by $3 \mathrm{~km} / \mathrm{h}$. The smallest maximum research vehicle speed was obtained when travelling with a load $(14 \mathrm{~km} / \mathrm{h})$.

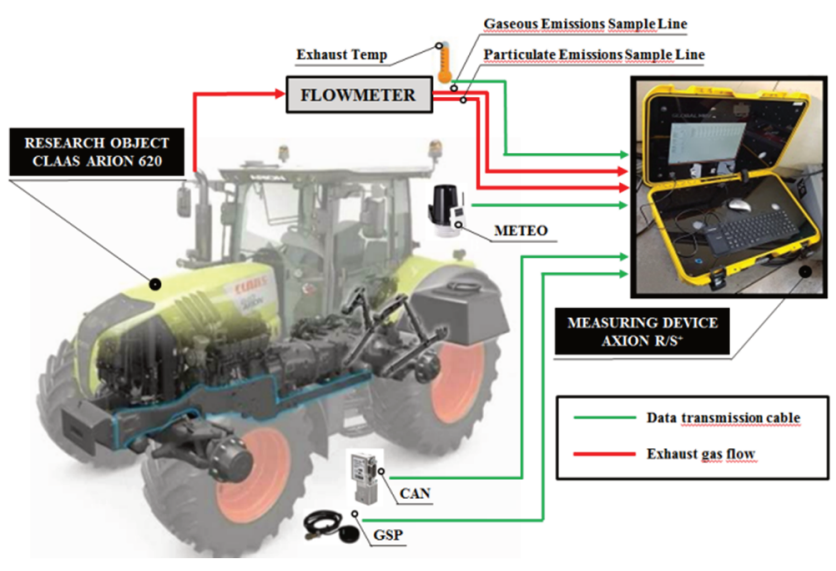

Fig. 1. Road-rail tractor with the PEMS apparatus

\subsection{Measuring apparatus}

A Micro PEMS (Portable Emission Measurement System) Axion R/S+ mobile analyzer was used for the tests (Fig.1). It made it possible to measure exhaust emissions of various components, such as: carbon dioxide $\left(\mathrm{CO}_{2}\right)$, carbon monoxide $(\mathrm{CO})$, hydrocarbons $(\mathrm{HC})$, nitrogen oxides $\left(\mathrm{NO}_{\mathrm{x}}\right)$ and particulate matter (PM). NDIR (Nondispersive Infrared Sensor) and electrochemical analyzer were used to measure the concentrations of these substances. In the case of PM measurement, a method based on Laser Scatter was used.

The performed tests included the measurements of harmful exhaust emissions in real operating conditions and were divided into three stages. The first of these included an unladen drive on an asphalt road with a vehicle equipped with herringbone tires, increasing traction. In the second (unladen journey) and third (laden) stage the tractor was equipped with a wheel set enabling traveling on rails. The vehicle travelled on the railway tracks owned by Łukasiewicz Research Network - Rail Vehicles Institute "TABOR". Based on the research results, the ecological indicators, exhaust emission were determined in both cases and the specific fuel consumption was determined using the carbon balance method. All measured data was recorded at a frequency of $1 \mathrm{~Hz}$. 


\section{Results analysis}

\subsection{Share of operating time}

The driving parameters recorded during the tests were used to determine the operating time share characteristics in the speed-acceleration ranges $(\mathrm{V}-\mathrm{a})$. Figure 2 shows the operating time share of the road-rail tractor on the road and on the track without load and on the track with the load in open-closed compartments.
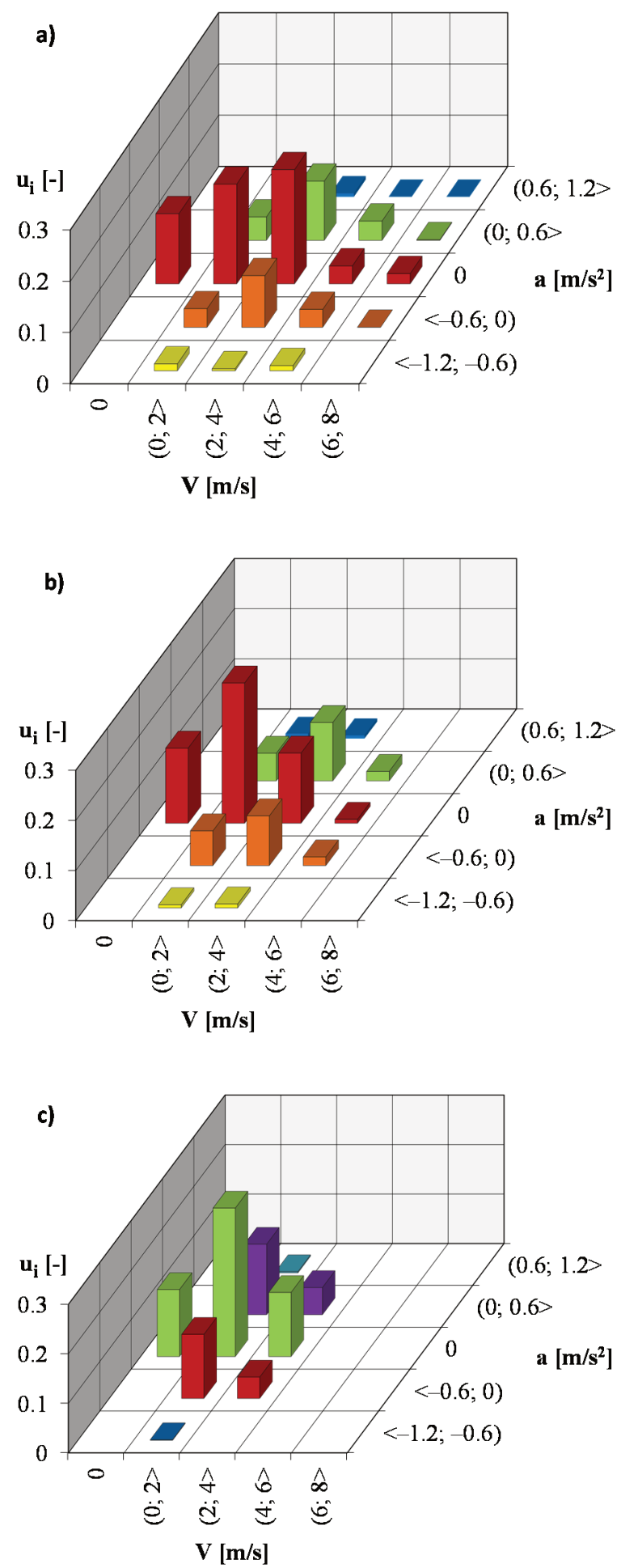

Fig. 2. Operating time share for the road-rail tractor: a) on the road without load, b) on track without load c) on track with load
The distribution of operating parameters includes the range of speed and acceleration values, with the highest values reaching: $22 \%$ - the point defined by a single interval described by values $(2 \mathrm{~m} / \mathrm{s} ; 4 \mathrm{~m} / \mathrm{s}\rangle$ and $0 \mathrm{~m} / \mathrm{s}^{2}$ (on road), $28 \%$ - the point defined by the interval $(0 \mathrm{~m} / \mathrm{s} ; 2 \mathrm{~m} / \mathrm{s}\rangle$ for acceleration of $0 \mathrm{~m} / \mathrm{s}^{2}$ (unladen on track) and $35 \%$ - single measurement window determined in the speed range $(0 \mathrm{~m} / \mathrm{s} ; 2 \mathrm{~m} / \mathrm{s}\rangle$ and acceleration of $0 \mathrm{~m} / \mathrm{s}^{2}$. For the whole operating range including the velocity and acceleration values between $\langle 0 \mathrm{~m} / \mathrm{s} ; 6 \mathrm{~m} / \mathrm{s}\rangle$ and $\left\langle-0.6 \mathrm{~m} / \mathrm{s} 2 ; 0.6 \mathrm{~m} / \mathrm{s}^{2}\right\rangle$ a very similar distribution of the operating time share characteristics was obtained for all the measured drive tests. During the road tests the vehicle was characterized by a larger range of operating parameters variability than in the other two drives.

\subsection{Exhaust emissions}

During the tests, the specific exhaust emission values were determined. All results were referenced to the Stage IIIB emission norm for internal combustion engines with a power in the range $75 \mathrm{~kW} \leq \mathrm{P}<560 \mathrm{~kW}$ (Figs 3-6). Based on this analysis, it can be stated:

- The specific emission of carbon monoxide obtained during the unladen drive on rail track was equal to value $0.76 \mathrm{~g} / \mathrm{kWh}$, while the emission value for travel on the road was almost five times higher and amounted to 3.64 $\mathrm{g} / \mathrm{kWh}$. When laden and on track of research object, a specific emission of $2.21 \mathrm{~g} / \mathrm{kWh}$ was obtained. All the obtained values met carbon monoxide limit of the Stage IIIB emission standard which is $5.0 \mathrm{~g} / \mathrm{kWh}$.

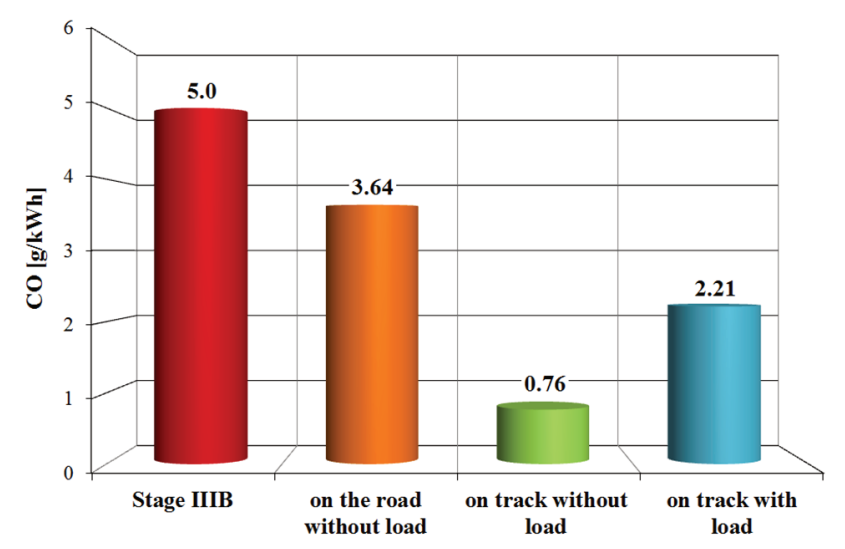

Fig. 3. Specific emission of carbon monoxide for the road-rail tractor traveling on the road and on track without load and on track with load

- With respect to the specific hydrocarbon emission, a lower value of $0.2 \mathrm{~g} / \mathrm{kWh}$ was obtained during the unladen drive. When travelling on the track when laden resulted in emission of $0.94 \mathrm{~g} / \mathrm{kWh}$. The highest $\mathrm{HC}$ emission value of $1.39 \mathrm{~g} / \mathrm{kWh}$ was obtained when travelling on the road. All of the completed trips exceeded the hydrocarbons emission limit value defined in Stage IIIB standard, defined as $0.19 \mathrm{~g} / \mathrm{kWh}$. The results obtained for track driving of research object are included in the limits introduced by the Stage II norm, while those obtained during road tests only meet the Stage I norm. 


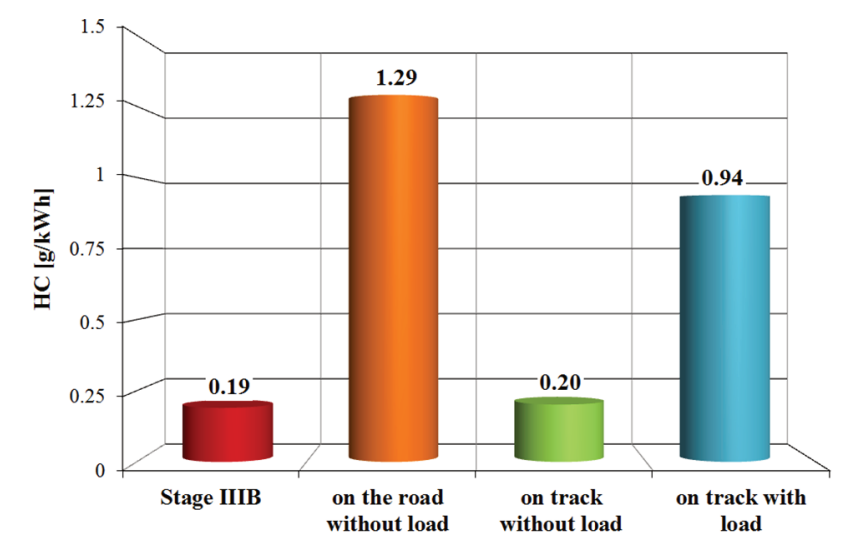

Fig. 4. Specific hydrocarbons emission for a road-rail tractor travelling on the road and on track without load and on track with load

- During the tests the smallest specific emission value of $\mathrm{NO}_{\mathrm{x}}(3.71 \mathrm{~g} / \mathrm{kWh})$ was obtained for the unloaded drive on the track. Travelling when loaded was characterized by a value of up to $10 \%$ higher, while for the drive on the road, the obtained value was $1.3 \mathrm{~g} / \mathrm{kWh}$ higher and reached $5.0 \mathrm{~g} / \mathrm{kWh}$. Neither of the measured drives, on the track with and without load, as well as on the road met the $\mathrm{NO}_{\mathrm{x}}$ emission limit of Stage IIIB norm, which is $3.3 \mathrm{~g} / \mathrm{kWh}$. However, they did meet the limit by the Stage II $(6.0 \mathrm{~g} / \mathrm{kWh})$.

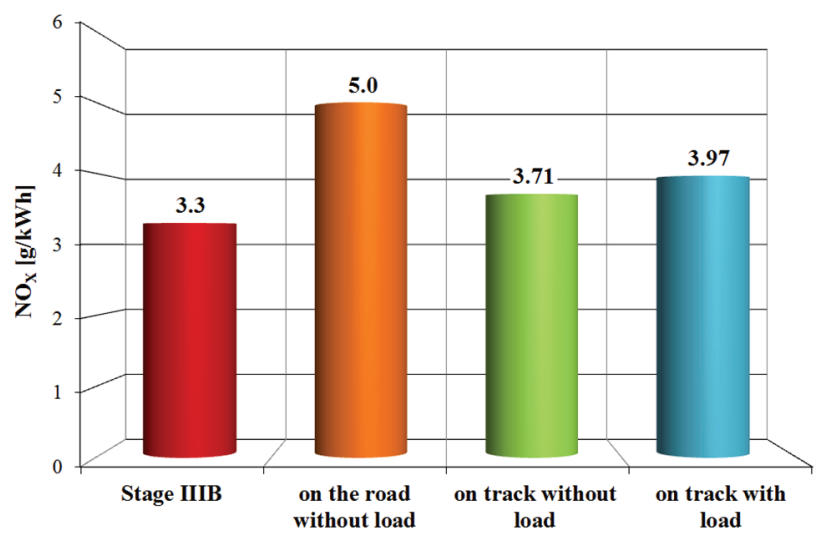

Fig. 5. Specific emission of nitrogen oxides for a road-rail tractor travelling on the road and on track without load and on track with load

- The specific emission of particulate matter obtained for the unladen drive on track was $0.01 \mathrm{~g} / \mathrm{kWh}$, while

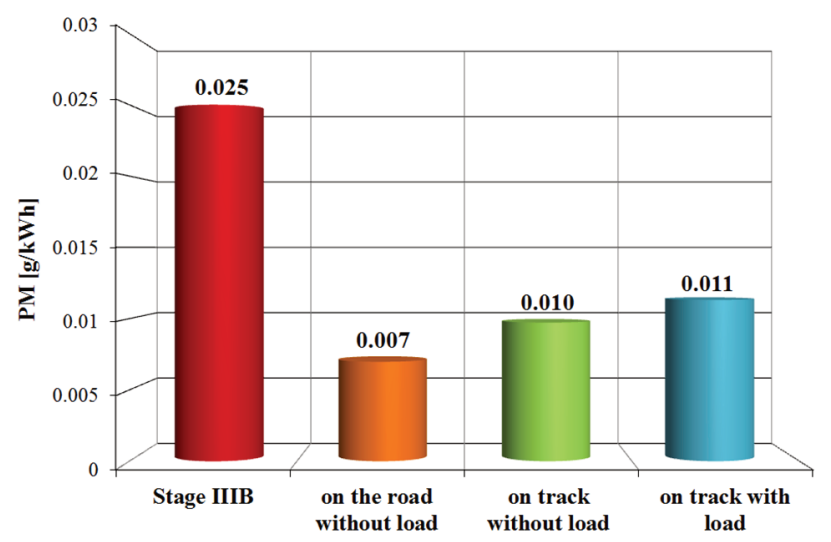

Fig. 6. Specific emission of particulate matter for a road-rail tractor travelling on the road and on track without load and on track with load for the road it was $0.003 \mathrm{~g} / \mathrm{kWh}$ lower and amounted to $0.007 \mathrm{~g} / \mathrm{kWh}$. The highest emission value equal to $0.011 \mathrm{~g} / \mathrm{kWh}$ was obtained for the vehicle travelling on the track with load. All of the measured test drives were in line with the Stage IIIB PM limit of 0.025 $\mathrm{g} / \mathrm{kWh}$.

The performed tests and their results were supplemented by determining the specific emission of carbon dioxide and fuel consumption obtained for all the tested drive situations of the road-rail tractor (Figures 7 and 8).

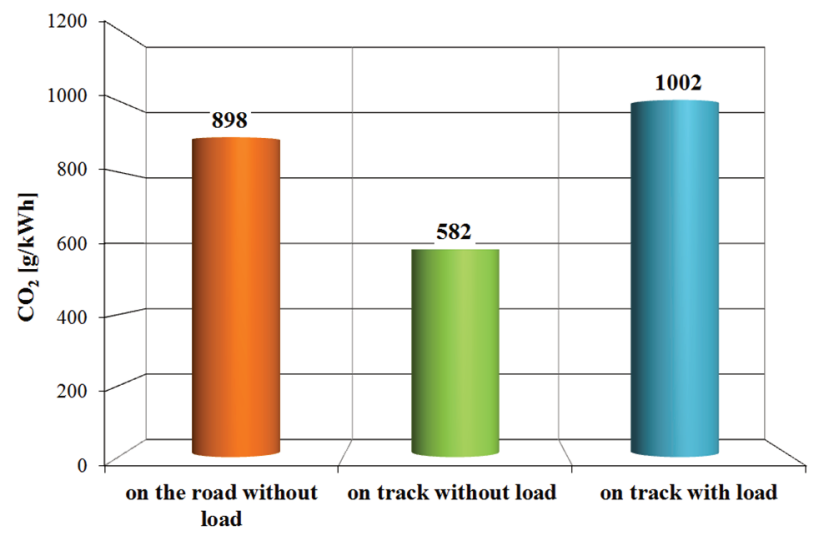

Fig. 7. Specific emission of carbon dioxide for a road-rail tractor travelling on the road and on track without load and on track with load

According to the analysis of the obtained data, the smallest specific emission of $\mathrm{CO}_{2}$ at the level of 582 $\mathrm{g} / \mathrm{kWh}$, and thus the lowest fuel consumption $(4.13 \mathrm{~kg} / \mathrm{h})$ was observed for the unloaded drive on the track. The values of the specific carbon dioxide emission obtained for road travel were over $150 \%$ of that, while the obtained fuel consumption was higher by almost $1 \mathrm{~kg} / \mathrm{h}$. The largest $\mathrm{CO}_{2}$ emission values $(1002 \mathrm{~g} / \mathrm{kWh})$, as well as the highest fuel consumption $(5.47 \mathrm{~kg} / \mathrm{h})$ was obtained when travelling on the track and pulling load.

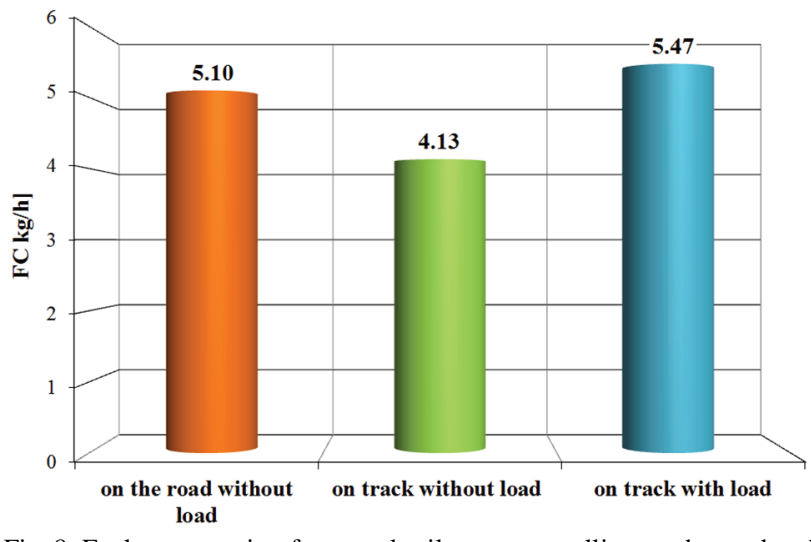

Fig. 8. Fuel consumption for a road-rail tractor travelling on the road and on track without load and on track with load

\section{Results analysis}

The exhaust emissions measurement from a road-rail vehicle in real operating conditions allowed determining the time density characteristics and the specific emission of engine exhaust components. The fuel consumption was also determined using data on the work done by the drive system. The obtained time density characteristics of the vehicle 
in speed-acceleration intervals while travelling on the road and track with and without load have shown similar distribution, which allowed for a comparative analysis. It is related to, among other things, with similar values of average vehicle speed and acceleration.

The unladen drive along the track was characterized by the lowest specific emission value of carbon monoxide and hydrocarbons due to the limited variability of engine operating parameters, and this is associated with more efficient thermodynamic processes. This is mainly related to the characteristics of the engine, at high loads the injected fuel dose is not thoroughly mixed resulting in incomplete combustion. The unladen drive on the track was also characterized by the smallest specific emission value of nitrogen oxides. This is due to the fact that both during the travel on the road and on the track with the load, the vehicle engine was under larger load, even though it is associated with an increase in temperature in the combustion chamber, and a direct impact on the $\mathrm{NO}_{\mathrm{x}}$ emission. In the case travel on the road the specific emission of particulate matter yielded the smallest values from all tests. PM emission is greatly affected by variable engine load, which involves the need to bring more fuel to the combustion chamber, which can lead to an increase in local partial and incomplete combustion in the combustion chamber. However, the exhaust aftertreatment system used - the DPF filter effectively limited their emission. The best ecological indicators based on gaseous exhaust emissions were obtained when driving on the track without load. Differences in fuel consumption result from the fact that when traveling on the track with load and on the road the vehicle encountered greater rolling resistance and achieved higher speed values, which translated directly to higher engine load. Emission of carbon dioxide is closely related to fuel consumption, therefore the nature of its value is proportional to the obtained fuel consumption values.

The test results obtained in the subsequent stages of the research can be used to assess the ecological indicators, but only by taking into account the operating conditions, including a larger engine loads, both in road and rail work. In order to improve the assessment of particulate emissions, it will be extremely useful to also measure their dimensional distribution, which is planned for further research.

\section{Nomenclature}

a acceleration

$\mathrm{CO}$ carbon monoxide

$\mathrm{CO}_{2}$ carbon dioxide

$\mathrm{HC}$ hydrocarbons

NDIR nondispersive infrared sensor

$\mathrm{NO}_{\mathrm{x}} \quad$ nitrogen oxides
$\mathrm{P} \quad$ power

PEMS portable emission measurement system

PM particulate matter

RDE real driving emissions

$\mathrm{u}_{\mathrm{i}} \quad$ share of working time

$\mathrm{V}$ velocity

\section{Bibliography}

[1] BRYK, K., ŁUKASZEWSKI, K., MEDWID, M. Simulation studies of safety against derailment of a road-rail vehicule Class Arion 620. International Scientific Conference. Transport of the 21th century. Arłamów 2016.

[2] DASZKIEWICZ, P., ANDRZEJEWSKI, M. Preliminary analyzes in terms of the possibility of reducing energy consumption by the SM42 locomotive used in trackworks. MATEC Web Conf. 2017, 118 00014. DOI: 10.1051/matecconf $/ 201711800014$

[3] Directive 97/68/EC of the European Parliament and of the Council of 16 December 1997 on the approximation of the laws of the Member States relating to measures against the emission of gaseous and particulate pollutants from combustion engines to be installed in non-road mobile machinery.

[4] Directive 2004/ 26/EC of the European Parliament and of the Council of 21 April 2004 amending Directive 97/68/EC on the approximation of the laws of the Member States relating to measures against the emission of gaseous and particu-

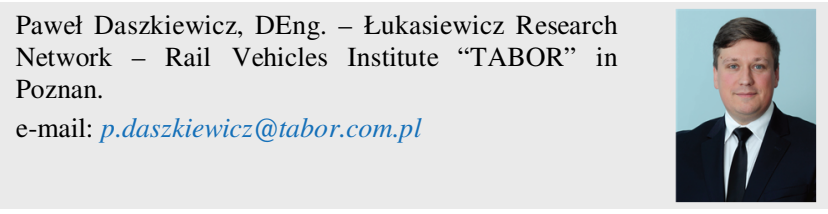

late pollutants from internal combustion engines to be installed in non-road mobile machinery.

[5] MEDWID, M., STAWECKI, W., CZERWIŃSKI, J., JAKUSZKO, W. Multi-purpose rail-road tractor of the new generation. Rail Vehicles. 2016, 3.

[6] MARCINIAK, Z., STAWECKI, W., PIELECHA, I., PIELECHA, J. Ecological aspects of diesel rail vehicles exploited on Polish rail lines. Logistyka. 2010, 4.

[7] OŻÓG, M. Requirements for limitation of the diesel exhaust fumes by rolling stock and consequences for railway undertakings. TTS Technika Transportu Szynowego. 2008, 5-6.

[8] RYCHLIK, A. Commercial vehicles fuel consumption measurement methods. Maintenance and Reliability. 2006, 4.

[9] STAWECKI, W., MARCINIAK, Z., PIELECHA, I., PIELECHA, J. Ecological aspects of the modernization of diesel locomotives in Poland. Prace Naukowe Politechniki Warszawskiej. Transport. 2013, 98.

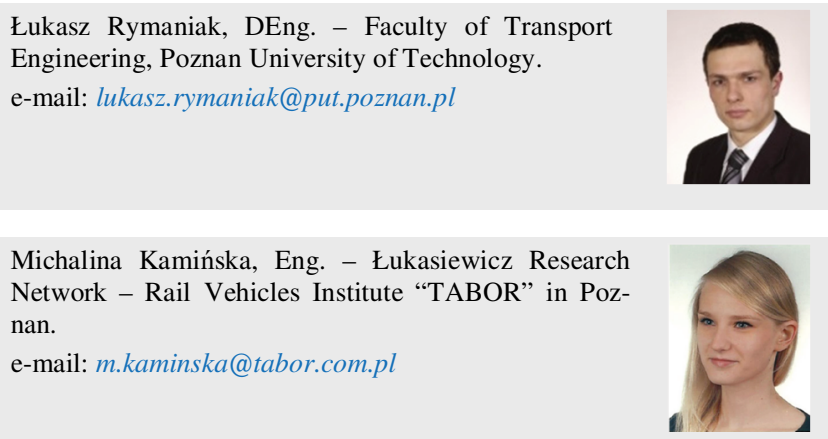

